\title{
K-MEANS CLUSTERING UNTUK PEMETAAN DAERAH RAWAN DEMAM BERDARAH
}

\author{
Suprihatin 1); Yustina Retno Wahyu Utami ${ }^{2)}$; Didik Nugroho ${ }^{3)}$ \\ 1) Program Studi Sistem Informasi, STMIK Sinar Nusantara Surakarta \\ 2)3) Program Studi Teknik Informatika, STMIK Sinar Nusantara Surakarta \\ ${ }^{1)}$ suprihatin111@gmail.com; ${ }^{2)}$ yustina_retno@sinus.ac.id; ${ }^{3)}$ didikhoho@sinus.ac.id
}

\begin{abstract}
District Nogosari is one of the dengue-prone areas in Boyolali District. During the period of 2012 to 2014, there was a significant increase in dengue cases at Boyolali district. For the reasons above, the study is focused on how to cluster Areas DHF-Prone using K-Means method. Clustering is based on the parameter of the number of dengue cases in the sporadic and endemic zones. There are several types of data collection methods that include: observation, interview, and literature study. Design of this proposed system use modeling language the context diagram and data flow diagram. The system is implemented using PHP Programming Language and MYSQL database. This system cluster 3 level zones of Endemic and 3 level zones of Sporadic based on geographic information systems. The result of system testing using the silhouette coefficient on the sporadic zone is the average coefficient for level 1 is 0.837 , level 2 is 0.858 , and level 3 is 0.773 that means the object has been in the right group. The proposed system is expected to be a consideration in preventing, controlling and eradicating dengue hemorrhagic fever.

Keywords: Endemic, Sporadic, K-Means clustering, Dengue hemorrhagic fever.
\end{abstract}

\section{PENDAHULUAN}

Selama kurun waktu tahun 2012 sampai 2014 Kabupaten Boyolali mengalami peningkatan kasus DBD yang cukup signifikan. Kecamatan Nogosari merupakan salah satu daerah endemis DBD di Kabupaten Boyolali. Dengan sistem informasi geografis pemetaan daerah rawan DBD di kecamatan Nogosari menggunakan Pengelompokan dengan metode K-Means diharapkan dapat menjadi pertimbangan dalam tindakan pencegahan, pengendalian dan pemberantasan DBD. Parameter yang digunakan dalam perancangan SIG Pemetaan DBD ini adalah data hasil data kasus demam berdarah per desa wilayah kecamatan Nogosari. Dan dikelompokkan menjadi 3 level yaitu level 1,level 2 dan level 3 zona Endemis atau level 1, level 2 dan level 3 zona Sporadis dan Bebas. Rumusan masalah yang akan dibahas adalah Bagaimana Membuat Sistem Informasi Geografis Pemetaan Daerah Rawan Demam Berdarah Menggunakan Metode K-Means Di Kecamatan Nogosari Kabupaten Boyolali.

Tujuan dari penelitian ini adalah membuat Sistem Informasi Geografis Pemetaan Daerah Rawan Demam Berdarah di Kecamatan Nogosari Kabupaten Boyolali. Pengelompokan daerah rawan Demam berdarah Terdiri dari 2 tahap yaitu:
1. Pengklasifikasi Zona Rawan demam berdarah menghasilkan zona endemis, sporadis dan bebas menggunakan aturan dari UPTD Puskesmas Nogosari.

2. Selanjutnya setiap kategori di kelompokkan mengunakan metode $k$ means clustering menghasilkan tingkat/ level dari setiap kategori.

\section{TINJAUAN PUSTAKA}

\subsection{Sistem Informasi Geografis}

Sistem informasi yang berfungsi untuk mengelola data yang berupa informasi keruangan (spasial). Dalam Bahasa inggris, SIG disebut Geographics Information System (GIS). Informasi spasial berupa posisi koordinat suatu objek, luasan wilayah, dan panjang garis yang diproyeksikan kedalam sistem koordinat. Selain informasi spasial, data tentang keterangan (atribut) suatu objek, luasan wilayah, dan panjang garis merupakan bahan-bahan yang diolah dalam Sistem Informasi Geografis[1].

\section{$2.2 \quad$ Algoritma $K$-Means}

Algoritma K-Means menggunakan proses secara berulang-ulang untuk mendapatkan basis data cluster. Dibutuhkan jumlah cluster awal yang diinginkan sebagai masukan dan menghasilkan titik centroid akhir sebagai 
output. Metode K-Means akan memilih pola $\mathrm{k}$ sebagai titik awal centroid secara acak atau random. Jumlah iterasi untuk mencapai cluster centroid akan dipengaruhi oleh calon cluster centroid awal secara random[2].

\subsection{Penelitian Sebelumnya}

Penelitian sebelumnya mengunakan $K$ Means Clustering untuk menentukan lahan usaha tambang berbasis sistem informasi geografi (SIG). Metode K-Means Clustering digunakan untuk pengelompokkan potensi bahan tambang yang terdapat di satu wilayah berdasarkan kriteria keruangan (spasial) dengan mengacu pada karakteristik bukan keruangan (a-spasial). Hasil analisis merupakan area potensi yang secara spasial dan a-spasial merupakan daerah potensi bahan tambang yang layak untuk dijadikan lahan usaha pertambangan. Daerah potensi ini diharapkan menjadi masukan dalam menyusun kebijakan mengenai penetapan wilayah pertambangan[3].

Penelitian kedua mengenai persebaran dan tingkat kerentanan terhadap DBD di Kecamatan Banjarsari, Kota Surakarta dengan menggunakan metode penginderaan jauh. Parameter yang digunakan adalah penggunaan lahan, kepadatan lingkungan, pola pemukiman, kepadatan penduduk, jarak terhadap sungai dan jarak terhadap TPS Sementara. Hasil tingkat kerentanan : Sangat rentan, Rentan, Agak Rentan,dan daerah non pemukiman [4].

Penelitian berikutnya tentang kemampuan citra hasil penginderaan jauh dan SIG dalam penentuan faktor - faktor lingkungan fisik untuk pemetaan daerah rawan DBD dan mengetahui sebaran DBD berdasarkan peta sebaran kasus, tempat, dan waktu mulai tahun 2005 sampai dengan 2010 serta menentukan tingkat kerawanan DBD berdasarkan variabel lingkungan dan kejadian $\mathrm{DBD}[5]$.

\section{METODE PENELITIAN}

\subsection{Metode Pengumpulan Data}

Metode pengumpulan data yang digunakan peneliti adalah sebagai wawancara dan observasi serta studi pustaka.

\section{A. Metode Wawancara dan Observasi}

Hasil wawancara di UPTD Puskermas Nogosari yaitu data kriteria yang digunakan untuk mengelompokan suatu daerah menjadi daerah yang Endemis, Sporadis dan Bebas Demam Berdarah.

Peneliti melaksanakan observasi terhadap proses penentuan daerah rawan demam berdarah pada Bidang Pencegahan dan Pemberantasan Penyakit Menular (P3M).

\section{B. Metode Studi Pustaka}

Pustaka yang peneliti gunakan terkait dengan sistem Informasi, pemrograman PHP, sistem informasi geografis, Google Maps, Metode K-Means serta topik tentang Daerah Rawan Demam Berdarah.

\subsection{Metode Pengembangan Perangkat Lunak}

\section{A. Analisis Sistem}

Tahap analisa adalah kegiatan penentuan klasifikasi data untuk pemetaan demam berdarah. Kecamatan Nogosari merupakan salah satu daerah endemis Demam Berdarah di Kabupaten Boyolali. Peningkatan kasus demam berdarah yang terjadi karena belum ada sistem yang digunakan untuk membantu program pencegahan, pengendalian dan pemberantasan di tiap daerah kerja. Disini peneliti menggunakan Metode K-Means dengan parameter banyaknya kemunculan kasus dengan tujuan untuk mengelompokkan daerah rawan DBD menjadi 3 level yaitu level 1, level 2 dan level tiga zona Endemis atau level 1,level 2 dan level tiga zona Sporadis dan Bebas.

\section{B. Desain Sistem}

Desain sistem dilakukan dengan perancangan terstruktur yaitu dengan penyusunan: Diagram Konteks, Hierarchy Input Proses Output (HIPO). Data Flow Diagram (DFD), Entity Relationship Diagram (ERD), Desain Database, Desain Input, Desain Output dan desain pelaporan.

\section{Implementasi Sistem}

Pada tahapan ini dilakukan coding program, bahasa pemrograman PHP, Google Maps API dan database MySQL. Software dan hardware yang digunakan adalah sebagai berikut :

1. Software: Sublime Text3, XAMPP, Google Chrome dan Google Earth.

2. Hardware: Laptop Spesifikasi sebagai berikut: Prosesor AMD A8-4500M, RAM 4GB, Harddisk 500 GB dan Modem.

\section{Metode Pengujian}

1) Pengujian Fungsional

Pengujian program dengan Test input dan output untuk fungsi tanpa memperhatikan prosesnya. Pada pengujian ini kebenaran sistem yang diuji dilihat berdasarkan keluaran yang dihasilkan dari masukan yang diberikan.

2) Uji Validitas Cluster (Koefisien Silhouette)

Pengujian validitas Cluster menggunakan metode koefisien silhouette. Nilai-nilai 
koefisien silhouette menunjukkan penilaian desa terhadap cluster. Rata-rata koefisien silhouette dari seluruh objek dalam suatu cluster menunjukkan seberapa dekat kemiripan objek dalam suatu cluster yang juga menunjukkan seberapa tepat objek telah dikelompokkan.

\section{IV.HASIL DAN PEMBAHASAN}

\subsection{Kriteria Penentuan Daerah Rawan Demam Berdarah}

Kriteria dalam penentuan daerah rawan demam berdarah berdasarkan data kasus demam berdarah tiap desa wilayah kecamatan Nogosari 3 tahun terakhir tersajikan pada Tabel 1.

Tabel 1. Data Kasus Demam Berdarah Kecamatan Nogosari Tahun 2014

\begin{tabular}{|r|l|c|c|c|c|c|c|}
\hline \multirow{2}{*}{ No } & \multirow{2}{*}{ Desa } & \multicolumn{7}{|c|}{ Jumlah Kasus } \\
\cline { 3 - 8 } & & \multicolumn{2}{|c|}{2012} & \multicolumn{2}{|c|}{2013} & \multicolumn{2}{|c|}{2014} \\
\cline { 3 - 8 } & & $\mathrm{P}$ & $\mathrm{M}$ & $\mathrm{P}$ & $\mathrm{M}$ & $\mathrm{P}$ & $\mathrm{M}$ \\
\hline 1 & Glonggong & 0 & 0 & 3 & 0 & 8 & 0 \\
\hline 2 & Pulutan & 0 & 0 & 0 & 0 & 1 & 0 \\
\hline 3 & Rembun & 1 & 0 & 1 & 0 & 7 & 0 \\
\hline 4 & Ketitang & 1 & 0 & 10 & 0 & 11 & 0 \\
\hline 5 & Jeron & 0 & 0 & 3 & 0 & 6 & 0 \\
\hline 6 & Sembungan & 2 & 0 & 13 & 0 & 12 & 0 \\
\hline 7 & Potronayan & 0 & 0 & 3 & 0 & 7 & 0 \\
\hline 8 & Guli & 0 & 0 & 6 & 0 & 8 & 0 \\
\hline 9 & Keyongan & 0 & 0 & 5 & 0 & 7 & 1 \\
\hline 10 & Tegalgiri & 1 & 0 & 2 & 0 & 3 & 0 \\
\hline 11 & Pojok & 0 & 0 & 1 & 0 & 2 & 0 \\
\hline 12 & Bendo & 0 & 0 & 2 & 1 & 0 & 0 \\
\hline 13 & Kenteng & 0 & 0 & 6 & 0 & 10 & 0 \\
\hline
\end{tabular}

\subsection{Pengkategorian Zona Endemis, Sporadis dan Bebas.}

Penentuan daerah rawan demam berdarah di UPTD Kecamatan Nogosari yaitu

1. Endemis : Dalam 3 tahun terakhir ada kasus berturut-turut

2. Sporadis : Dalam 3 tahun terakhir ada kasus, tidak setiap tahun

3. Bebas : Dalam 3 tahun terakhir tidak ada kasus

Berikut adalah Tabel data kasus beserta penentuan Daerah Rawan DBD.

Tabel 2. Pengkategorian Zona Endemis, Sporadis dan Bebas.

\begin{tabular}{|c|c|c|c|c|c|c|c|c|c|}
\hline \multirow[t]{3}{*}{ Desa } & \multicolumn{6}{|c|}{ Jumlah Kasus } & \multicolumn{3}{|c|}{$\begin{array}{c}\text { Klasifikasi } \\
\text { Desa Th. } \\
2014\end{array}$} \\
\hline & \multicolumn{2}{|c|}{2012} & \multicolumn{2}{|c|}{2013} & \multicolumn{2}{|c|}{2014} & \multirow{2}{*}{ En } & \multirow{2}{*}{$\mathrm{Sp}$} & \multirow{2}{*}{ B } \\
\hline & $\mathrm{P}$ & $\mathrm{M}$ & $\mathrm{P}$ & $\mathrm{M}$ & $\mathrm{P}$ & $\mathrm{M}$ & & & \\
\hline Glonggong & 0 & 0 & 3 & 0 & 8 & 0 & 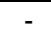 & 1 & - \\
\hline Pulutan & 0 & 0 & 0 & 0 & 1 & 0 & - & 1 & - \\
\hline Rembun & 1 & 0 & 1 & 0 & 7 & 0 & 1 & - & - \\
\hline
\end{tabular}

\begin{tabular}{|c|c|c|c|c|c|c|c|c|c|}
\hline \multirow[t]{3}{*}{ Desa } & \multicolumn{6}{|c|}{ Jumlah Kasus } & \multicolumn{3}{|c|}{$\begin{array}{c}\text { Klasifikasi } \\
\text { Desa Th. } \\
2014\end{array}$} \\
\hline & \multicolumn{2}{|c|}{2012} & \multicolumn{2}{|c|}{2013} & \multicolumn{2}{|c|}{2014} & \multirow{2}{*}{ En } & \multirow{2}{*}{ Sp } & \multirow{2}{*}{ B } \\
\hline & $P$ & $\bar{M}$ & $\mathrm{P}$ & $\mathrm{M}$ & $P$ & $\mathrm{M}$ & & & \\
\hline Ketitang & 1 & 0 & 10 & 0 & 11 & 0 & 1 & - & - \\
\hline Jeron & 0 & 0 & 3 & 0 & 6 & 0 & - & 1 & - \\
\hline Sembungan & 2 & 0 & 13 & 0 & 12 & 0 & 1 & - & - \\
\hline Potronayan & 0 & 0 & 3 & 0 & 7 & 0 & - & 1 & - \\
\hline Guli & 0 & 0 & 6 & 0 & 8 & 0 & - & 1 & - \\
\hline Keyongan & 0 & 0 & 5 & 0 & 7 & 1 & - & 1 & - \\
\hline Tegalgiri & 1 & 0 & 2 & 0 & 3 & 0 & 1 & - & - \\
\hline Pojok & 0 & 0 & 1 & 0 & 2 & 0 & - & 1 & - \\
\hline Bendo & 0 & 0 & 2 & 1 & 0 & 0 & - & 1 & - \\
\hline Kenteng & 0 & 0 & 6 & 0 & 10 & 0 & - & 1 & - \\
\hline
\end{tabular}

Keterangan

$\begin{array}{llll}\mathrm{P} & \text { : Penderita } & \mathrm{M} & : \text { : Meninggal } \\ \mathrm{En} & : \text { Endemis } & \mathrm{Sp} & : \text { Sporadis } \\ \mathrm{B} & : \text { Bebas } & & \end{array}$

4.3 Proses Penentuan tingkat kerawanan Suatu Daerah Terhadap DBD dengan Metode K-Means Clustering.

Proses Penentuan Tingkat Kerawanan Zona Endemis dengan Metode K-Means menggunakan dasar penentuan daerah rawan demam berdarah di UPTD Kecamatan Nogosari tersaji pada Tabel 2. Yang termasuk dalam kategori sporadis seperti yang disajikan Tabel 3.

Tabel 3. Dasar Penentuan Tingkat Kerawanan Zona Sporadis DBD

\begin{tabular}{|r|l|c|c|c|c|c|c|}
\hline \multirow{2}{*}{ No } & \multirow{2}{*}{ Desa } & \multicolumn{6}{|c|}{ Jumlah Kasus } \\
\cline { 3 - 8 } & & 2012 & \multicolumn{2}{|c|}{2013} & \multicolumn{2}{|c|}{2014} \\
\cline { 3 - 8 } & & $\mathrm{P}$ & $\mathrm{M}$ & $\mathrm{P}$ & $\mathrm{M}$ & $\mathrm{P}$ & $\mathrm{M}$ \\
\hline 1 & Glonggong & 0 & 0 & 3 & 0 & 8 & 0 \\
\hline 2 & Pulutan & 0 & 0 & 0 & 0 & 1 & 0 \\
\hline 3 & Jeron & 0 & 0 & 3 & 0 & 6 & 0 \\
\hline 4 & Potronayan & 0 & 0 & 3 & 0 & 7 & 0 \\
\hline 5 & Guli & 0 & 0 & 6 & 0 & 8 & 0 \\
\hline 6 & Keyongan & 0 & 0 & 5 & 0 & 7 & 1 \\
\hline 7 & Pojok & 0 & 0 & 1 & 0 & 2 & 0 \\
\hline 8 & Bendo & 0 & 0 & 2 & 1 & 0 & 0 \\
\hline 9 & Kenteng & 0 & 0 & 6 & 0 & 10 & 0 \\
\hline
\end{tabular}

Berikut merupakan tahap pengelompokan tingkat kerawanan zona Sporadis DBD menggunakan metode K-Means Means menjadi 3 level : Level 1(sedikit rawan), level 2 (rawan), level 3 (sangat rawan).

1. Menentukan Jumlah Cluster

Tahap pertama adalah menentukan jumlah cluster, dalam sistem ini akan menghasilkan 3 kelompok yang di identitaskan Cluster 1 atau level 1, Cluster 2 atau level 2 dan Cluster $3 /$ level 3

\section{Tentukan Nilai Centroid awal}


Tahap selanjutnya menentukan nilai centroid awal dengan mengambil data yang mewakili Cluster yang ditentukan pada tahap 1, seperti yang disajikan pada Tabel 4 .

Tabel 4. Tabel Centroid Awal Tingkat Kerawanan Zona Endemis DBD

\begin{tabular}{|c|c|c|c|c|c|c|c|}
\hline \multirow{2}{*}{ Level } & \multicolumn{5}{|c|}{ Jumlah Kasus } & \multirow{2}{*}{ Keterangan } \\
\cline { 2 - 7 } & 2012 & 2013 & \multicolumn{2}{|c|}{2014} & \\
\cline { 2 - 7 } & $\mathrm{P}$ & $\mathrm{M}$ & $\mathrm{P}$ & $\mathrm{M}$ & $\mathrm{P}$ & $\mathrm{M}$ & \\
\hline Level 1 & 0 & 0 & 2 & 1 & 0 & 0 & Desa Bendo \\
\hline Level 2 & 0 & 0 & 3 & 0 & 7 & 0 & $\begin{array}{l}\text { Desa } \\
\text { Potronayan }\end{array}$ \\
\hline \multirow{2}{*}{ Level 3 } & 0 & 0 & 5 & 0 & 7 & 1 & $\begin{array}{l}\text { Desa } \\
\text { Keyongan }\end{array}$ \\
\hline
\end{tabular}

3. Hitung jarak setiap data yang ada terhadap setiap Cluster.

Setelah menentukan nilai centroid awal langkah selanjutnya adalah hitung jarak setiap data yang ada terhadap setiap Cluster. Untuk menghitung jarak data yang ada terhadap setiap Cluster dapat menggunakan rumus Euclidian Distance di bawah:

$$
\begin{aligned}
& d(x, y)=\|x-y\|=\sqrt{\sum_{i=1}^{n}\left(x_{i}-y_{i}\right)^{2}} ; i=1,2,3, \ldots, n \\
& x=\text { Objek data } \\
& y=\text { Centroid }
\end{aligned}
$$

Menghitung jarak Desa Glonggong pada tiap cluster:

1. Desa Glonggong dengan pusat Cluster pertama

$$
\begin{aligned}
& =\sqrt{\begin{array}{l}
\left.(\mathbf{0}-\mathbf{0})^{2}+(\mathbf{0}-\mathbf{0})^{2}+(3-2)^{2}\right)+ \\
(\mathbf{0}-\mathbf{1})^{2}+(\mathbf{8}-\mathbf{0})^{2}+(\mathbf{0}-\mathbf{0})^{2}
\end{array}} \\
& =8.124
\end{aligned}
$$

2. Desa Glonggong dengan pusat Cluster kedua

$$
\begin{aligned}
& =\sqrt{\left.(\mathbf{0}-\mathbf{0})^{2}+(\mathbf{0}-\mathbf{0})^{2}+(\mathbf{3}-\mathbf{3})^{2}\right)+} \\
& =1
\end{aligned}
$$

3. Desa Glonggong dengan pusat Cluster ketiga

$$
\begin{aligned}
& =\sqrt{\left.(\mathbf{0}-\mathbf{0})^{2}+(\mathbf{0}-\mathbf{0})^{2}+(\mathbf{3}-\mathbf{5})^{2}\right)+} \\
& =2.449
\end{aligned}
$$

Hasil perhitungan selengkapnya disajikan pada Tabel 5.

Tabel 5. Jarak Antar Cluster

\begin{tabular}{|l|l|l|l|}
\hline \multicolumn{1}{|c|}{ Desa } & C1 & C2 & C3 \\
\hline Glonggong & 8.124 & 1 & 2.449 \\
\hline Pulutan & 2.449 & 6.708 & 7.874 \\
\hline Jeron & 6.164 & 1 & 2.449 \\
\hline
\end{tabular}

\begin{tabular}{|l|l|l|l|}
\hline \multicolumn{1}{|c|}{ Desa } & C1 & C2 & C3 \\
\hline Potronayan & 7.141 & 0 & 2.236 \\
\hline Guli & 9 & 3.162 & 1.73205 \\
\hline Keyongan & 7.746 & 2.236 & 0 \\
\hline Pojok & 2.449 & 5.385 & 6.48074 \\
\hline Bendo & 0 & 7.141 & 7.74597 \\
\hline Kenteng & 10.816 & 4.2427 & 3.31662 \\
\hline
\end{tabular}

4. Tentukan anggota dari suatu Cluster

Langkah selanjutnya adalah menentukan suatu data akan menjadi anggota dari suatu Cluster yang memiliki jarak terkecil dari pusat Cluster nya. Misalkan untuk data pertama, jarak terkecil diperoleh pada C3, sehingga data pertama akan menjadi anggota dari C3. Demikian juga untuk data kedua, jarak terkecil ada pada C3, maka data tersebut akan masuk pada C3. Posisi Cluster selengkapnya dapat di lihat di Tabel 6.

Tabel 6. Posisi Cluster pada Iterasi pertama

\begin{tabular}{|l|l|l|l|l|}
\hline \multicolumn{1}{|c|}{ Desa } & C1 & C2 & C3 & Ket \\
\hline Glonggong & 8.124 & 1 & 2.449 & L2 \\
\hline Pulutan & 2.449 & 6.708 & 7.874 & L1 \\
\hline Jeron & 6.164 & 1 & 2.449 & L2 \\
\hline Potronayan & 7.141 & 0 & 2.236 & L2 \\
\hline Guli & 9 & 3.162 & 1.732 & L3 \\
\hline Keyongan & 7.746 & 2.236 & 0 & L3 \\
\hline Pojok & 2.449 & 5.385 & 6.480 & L1 \\
\hline Bendo & 0 & 7.141 & 7.745 & L1 \\
\hline Kenteng & 10.816 & 4.242 & 3.316 & L3 \\
\hline
\end{tabular}

5. Hitung pusat Cluster baru.

Setelah menentukan termasuk Cluster mana langkah selanjutnya adalah menghitung pusat Cluster baru berikut merupakan penghitungan Cluster baru:

1) Untuk Cluster pertama terdiri dari desa Pulutan, Pojok dan Bendo sehingga :

$$
\begin{aligned}
& \mathrm{C}_{11}=(0+0+0) / 3=0 \\
& \mathrm{C}_{12}=(0+0+0) / 3=0 \\
& \mathrm{C}_{13}=(0+1+2) / 3=1 \\
& \mathrm{C}_{14}=(0+0+1) / 3=0.33 \\
& \mathrm{C}_{15}=(1+2+0) / 3=1 \\
& \mathrm{C}_{16}=(0+0+0) / 3=0
\end{aligned}
$$

2) Untuk Cluster kedua terdiri dari desa Glonggong, Jeron dan Bendo sehingga:

$$
\begin{aligned}
& \mathrm{C}_{21}=(0+0+0) / 3=0 \\
& \mathrm{C}_{22}=(0+0+0) / 3=0 \\
& \mathrm{C}_{23}=(3+3+3) / 3=3 \\
& \mathrm{C}_{24}=(0+0+0) / 3=0 \\
& \mathrm{C}_{25}=(8+6+7) / 3=7 \\
& \mathrm{C}_{26}=(0+0+0) / 3=0
\end{aligned}
$$


3) Untuk Cluster ke tiga terdiri dari desa Guli, Keyongan dan Kenteng sehingga:

$$
\begin{aligned}
& \mathrm{C}_{31}=(0+0+0) / 3=0 \\
& \mathrm{C}_{32}=(0+0+0) / 3=0 \\
& \mathrm{C}_{33}=(6+5+6) / 3=5.67 \\
& \mathrm{C}_{34}=(0+0+0) / 3=0 \\
& \mathrm{C}_{35}=(8+7+10) / 3=8.33 \\
& \mathrm{C}_{36}=(0+1+0) / 3=0.33
\end{aligned}
$$

6. Ulangi langkah 2 hingga posisi data sudah tidak mengalami perubahan

Tabel 7. Posisi Cluster pada Iterasi ke- 2

\begin{tabular}{|l|l|l|l|l|}
\hline \multicolumn{1}{|c|}{ Desa } & C1 & C2 & C3 & \multicolumn{1}{c|}{ Ket } \\
\hline Glonggong & 7.288 & 1 & 2.708 & C2 \\
\hline Pulutan & 1.054 & 6.708 & 9.273 & C1 \\
\hline Jeron & 5.395 & 1 & 3.559 & C2 \\
\hline Potronayan & 6.333 & 0 & 3 & C2 \\
\hline Guli & 8.608 & 3.162 & 0.577 & C3 \\
\hline Keyongan & 7.288 & 2.235 & 1.632 & C3 \\
\hline Pojok & 1.054 & 5.385 & 7.874 & C1 \\
\hline Bendo & 1.563 & 7.141 & 9.165 & C1 \\
\hline Kenteng & 10.3 & 4.242 & 1.732 & C3 \\
\hline
\end{tabular}

Karena pada iterasi ke-1 dan ke-2 (Tabel 6 dan Tabel 7) posisi Cluster tidak berubah, maka iterasi dihentikan dan hasil akhir yang diperoleh adalah 3 Cluster:

1. Cluster 1/Level 1 Zona Sporadis yaitu desa Pulutan, Pojok, dan Bendo

2. Cluster 2/Level 2 Zona Sporadis yaitu desa Glonggong, Jeron dan Potronayan

3. Cluster 3/ Level 3 Zona Sporadis yaitu desa Guli, Keyongan dan Kenteng

\subsection{Desain Sistem}

\section{Diagram Konteks}

Diagram konteks Slstem Informasi Geografis Pemetaan Daerah Rawan DBD disajikan pada Gambar 1.

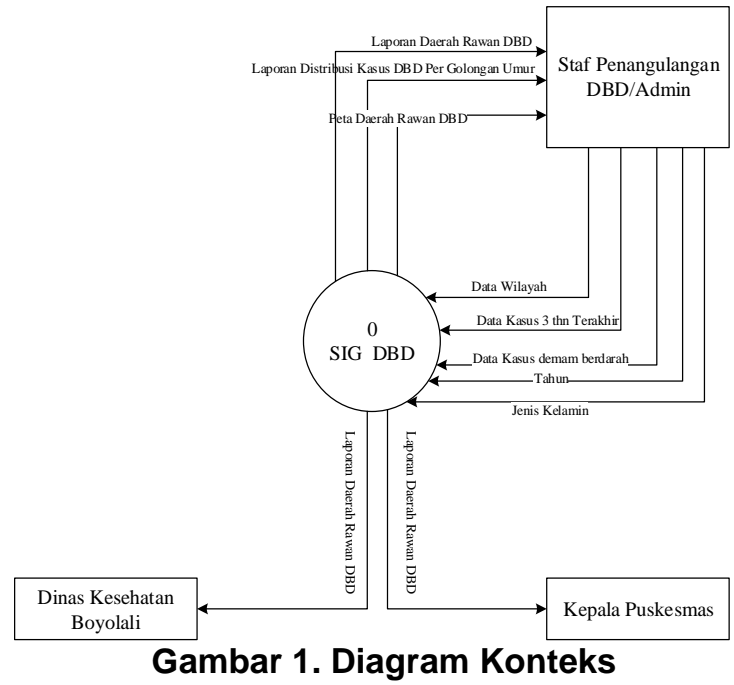

\section{Herarchy Input Proses Output (HIPO)}

HIPO atau diagram berjenjang dirancang secara khusus untuk menggambarkan struktur bertingkat guna memahami fungsi-fungsi dari modul-modul suatu sistem, HIPO juga dirancang umtuk menggambarkan modulmodul yang harus diselesaikan oleh program. Gambar HIPO disajikan pada Gambar 2.

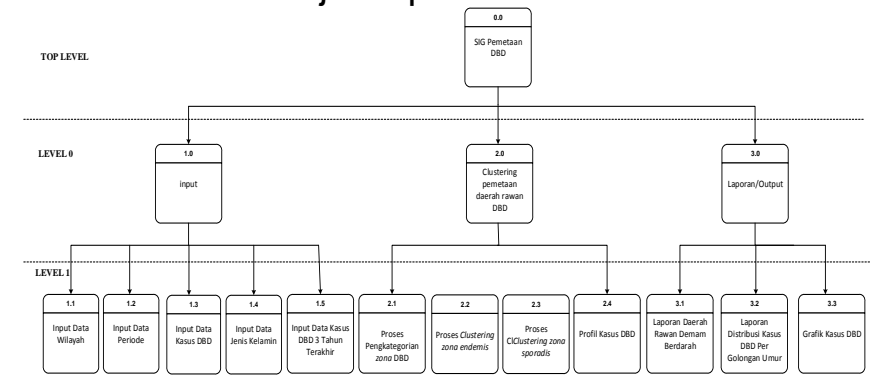

\section{Gambar 2. HIPO (Hierarchy Input Proses Output)}

\section{Data Flow Diagram}

\section{DFD Level 0}

Data flow diagram level 0 sistem informasi geografis pemetaan daerah rawan DBD disajikan pada Gambar 3.

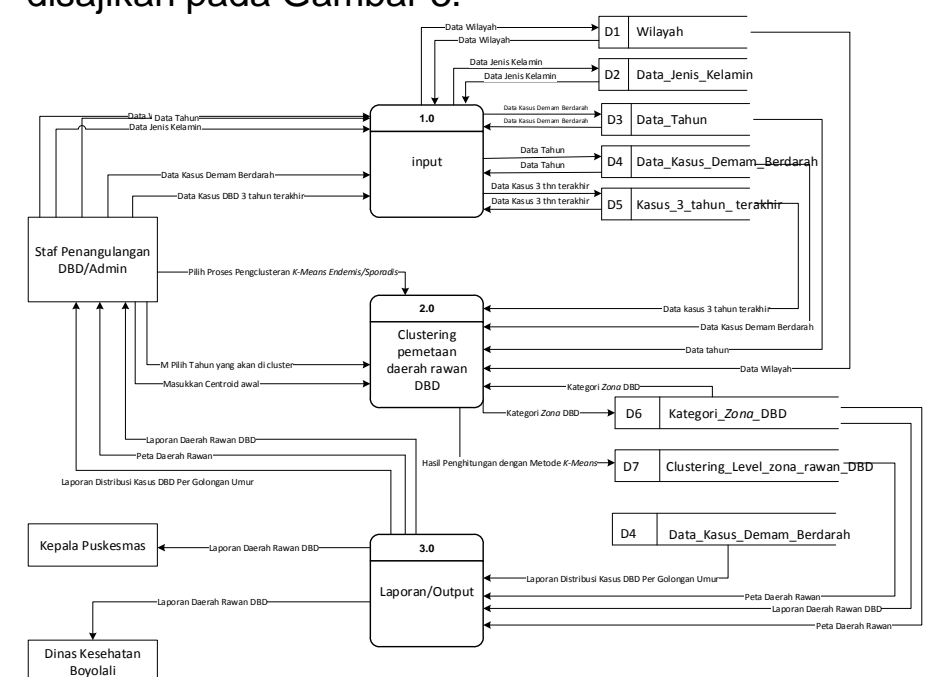

Gambar 3. DFD Level 0

Staf Penanggulangan DBD menginputkan beberapa data diantaranya adalah data jenis kelamin, data tahun, data wilayah dan data kasus DBD, masing-masing dimasukkan dalam Tabel sesuai data masukan. Inputan data kasus DBD 3 tahun terakhir akan masuk kedalam tabel kasus 3 tahun terakhir dimana Tabel tersebut digunakan untuk proses pengkategorian zona DBD. Setelah proses pengkategorian zona DBD maka hasil akan tersimpan di tabel kategori zona DBD. Yang selanjutnya digunakan untuk proses clustering level zona DBD dengan tabel kasus 3 tahun terakhir. Hasil dari proses clustering level zona 
DBD adalah zona DBD dengan level kerawanan suatu daerah.

2. DFD Level 1 Proses Input Data Master

Pada level 1 proses input data master admin memasukkan data wilayah, data jenis kelamin, Data Kasus DBD, Data pemetaan. DFD Level 1 Proses Input Master SIG Pemetaan DBD disajikan pada Gambar 4.
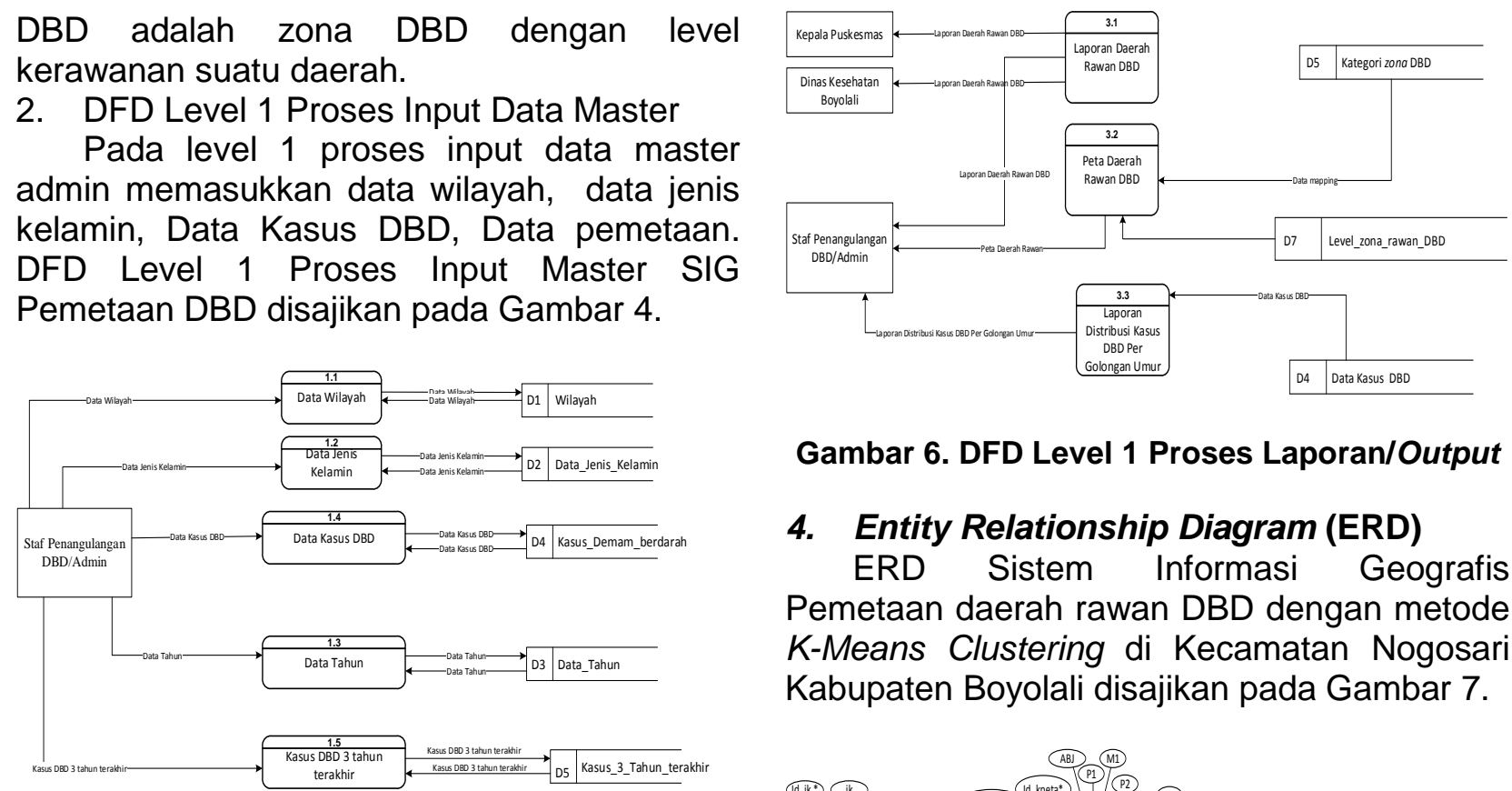

Gambar 6. DFD Level 1 Proses Laporan/Output

\section{Entity Relationship Diagram (ERD)}

ERD Sistem Informasi Geografis Pemetaan daerah rawan DBD dengan metode K-Means Clustering di Kecamatan Nogosari Kabupaten Boyolali disajikan pada Gambar 7.

Gambar 4. DFD Level 1 Proses Input Data Master

3. DFD Level 1 Proses K-Means Clustering

Proses Pengelompokan dalam sistem ini terdiri dari 4 proses yaitu proses pengkategorian zona DBD, proses clustering zona endemis DBD, proses clustering zona sporadis DBD dan Proses Profil Kasus DBD. DFD level 1 Proses K-Means Clustering disajikan pada Gambar 5.

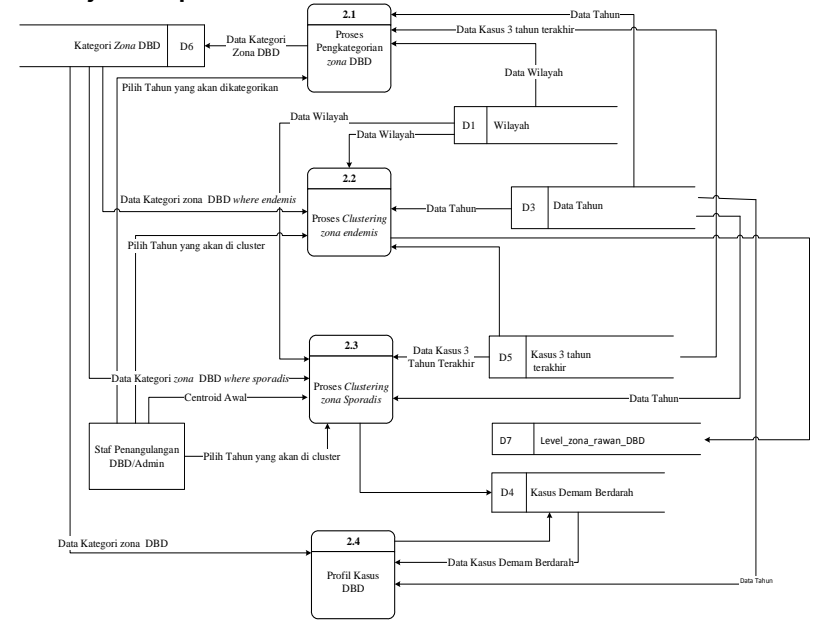

Gambar 5. DFD Level 1 Proses K-Means Clustering

\section{DFD Level 1 Proses Laporan/Output}

Pada proses ini sistem akan memberikan laporan berupa hasil pengelompokkan kasus dbd menjadi zona rawan DBD langsung secara interface kepada admin dan kepala puskesmas. Laporan pengelompokkan langsung diberikan ke user setelah memasukkan periode tahun yang sudah di olah di proses clutering. DFD Level 1 Proses

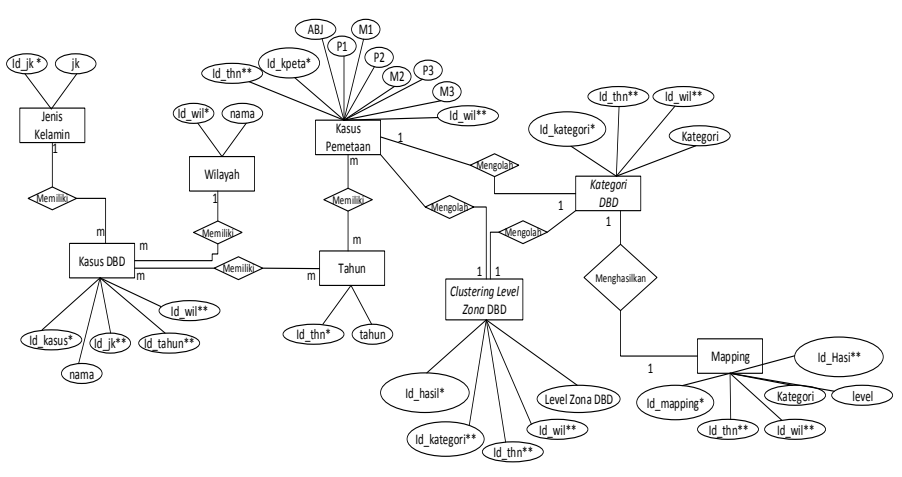

Gambar 7. ERD

\subsection{Implementasi Sistem}

1. Halaman Data Master Pemetaan Kasus DBD

Halaman data master pemetaan kasus DBD adalah halaman yang digunakan untuk mengelola data master pemetaan kasus DBD, terdapat fasilitas untuk menambah data master pemetaan kasus DBD. Halaman ini hanya bisa diakses oleh pengguna yang login sebagai admin. Halaman data master pemetaan kasus DBD ditunjukkan pada Gambar 8.

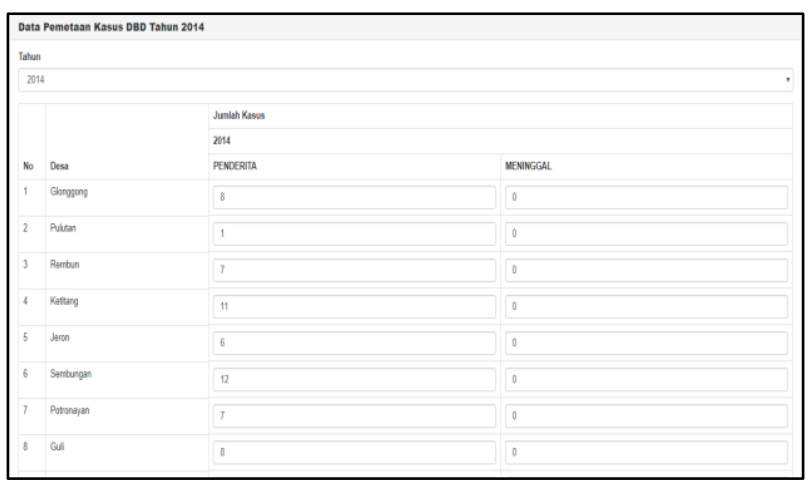

Gambar 8. Halaman Managemen Data Pemetaan Master Kasus DBD 
2. Halaman kategori zona DBD

Halaman kategori zona DBD digunakan untuk menampilkan hasil pengkategorian zona DBD. Digunakan sebagai dasar pengelompokkan per kategori zona DBD. Halaman kategori zona DBD ditunjukkan pada Gambar 9.

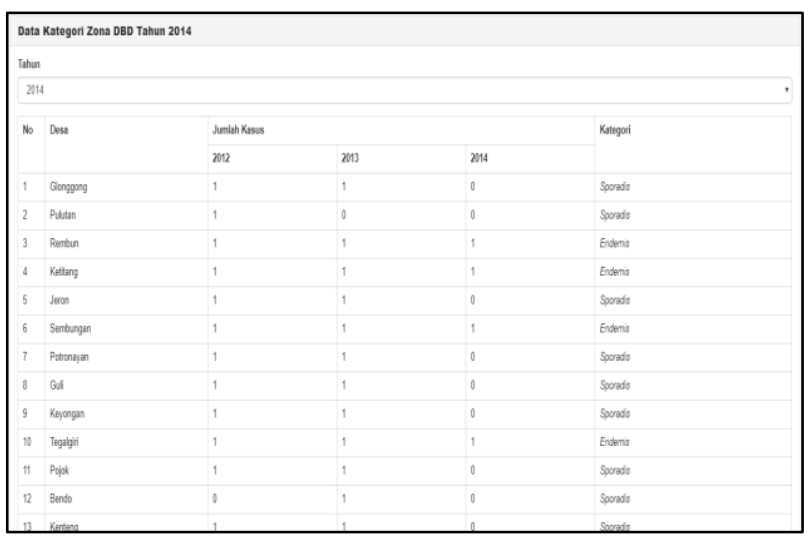

Gambar 9. Halaman kategori zona DBD

3. Halaman pengelompokkan level zona DBD dengan K-Means Clustering

Halaman Pengelompokkan level zona DBD dengan K-Means Clustering digunakan untuk menambahkan data centroid awal dan menampilkan data kasus pemetaan DBD berdasarkan kategori dari data master pemetaan untuk pengelompokkan level zona DBD metode k-means clustering. Untuk menambah kan centroid awal pada pemodelan terlebih dahulu admin harus memilih tahun yang akan dihitung dengan metode k-means. Halaman Pengelompokkan level zona DBD dengan K-Means Clustering ditunjukan pada Gambar 10.

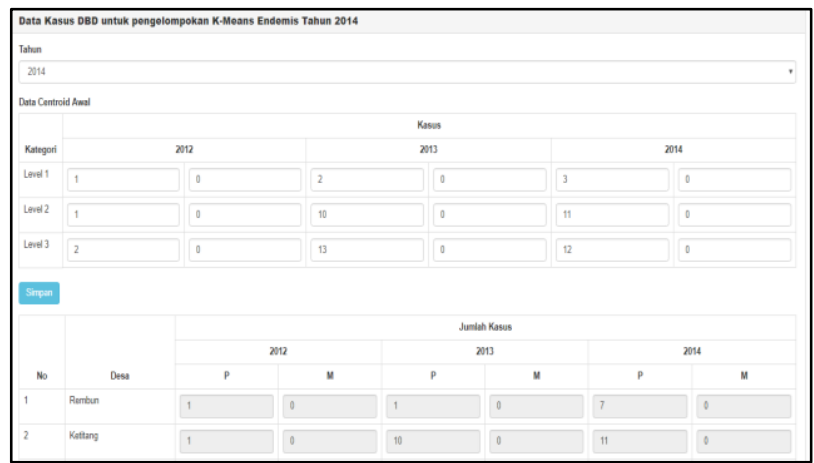

Gambar 10. Halaman Pemodelan K-Means Clustering

\section{Halaman Hasil K-Means Clustering}

Halaman hasil k-means clustering Level Zona DBD digunakan untuk melihat hasil perhitungan metode K-Means Clustering untuk mengelompokan level zona DBD dengan memilih tahun hasil yang akan dilihat. Halaman hasil K-Means Clustering. Halaman hasil k-means clustering Level Zona DBD ditunjukkan pada Gambar 11.

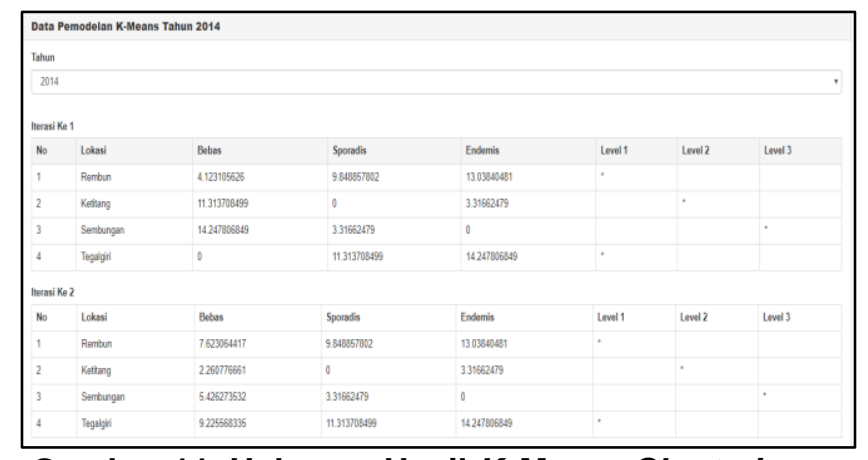

Gambar 11. Halaman Hasil K-Means Clustering Level Zona DBD

5. Halaman Pemetaan Daerah Rawan DBD dengan metode K-Means Clustering

Halaman Pemetaan Daerah Rawan DBD

dengan metode K-Means Clustering berbentuk peta pemetaan daerah rawan DBD dengan legenda daerah rawan desa tersebut. Untuk melihat pemetaan daerah rawan DBD terlebih dahulu pengguna harus memilih tahun. Halaman pemetaan DBD ditunjukkan pada Gambar 12.

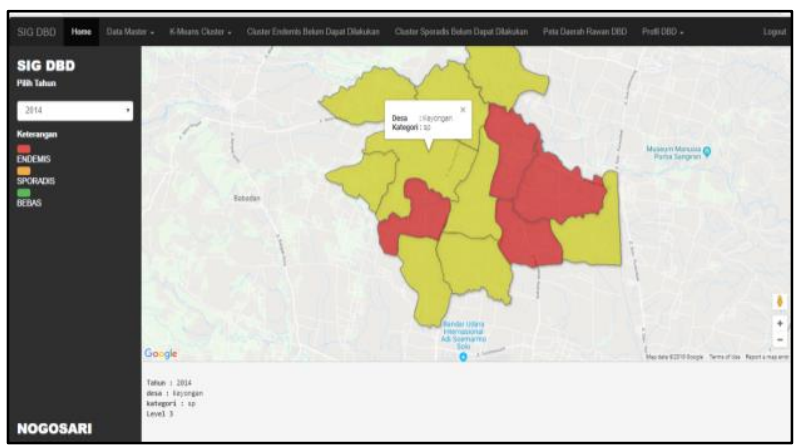

Gambar 12. Halaman Pemetaan Daerah Rawan DBD

6. Tampilan Laporan Distribusi Rawan DBD Pergolongan Umur

Tampilan laporan distribusi rawan DBD pergolongan umur dalam sistem ditunjukkan pada Gambar 13.

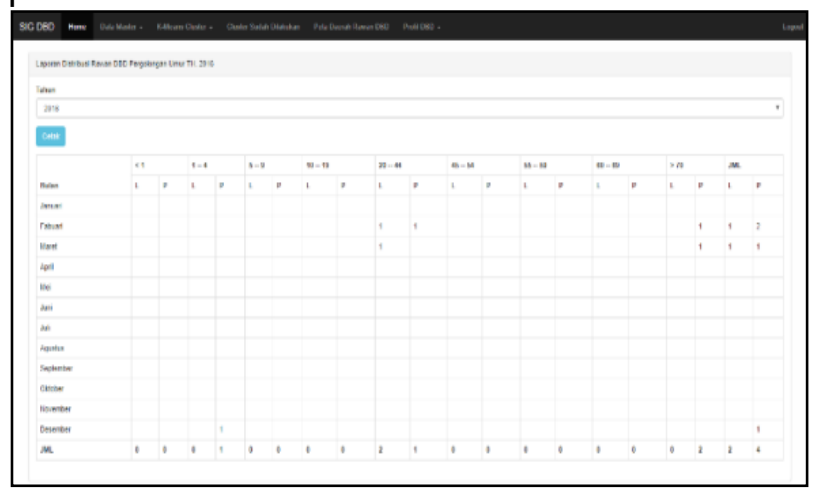

Gambar 13. Laporan Distribusi Rawan DBD Pergolongan Umur 
Pada laporan distribusi rawan DBD pergolongan umur pengguna dapat mencetak laporan dengan tombol cetak yang tersedia. Halaman laporan distribusi rawan DBD pergolongan umur dapat diakses dengan klik menu profil DBD kemudian pilih menu laporan distribusi rawan DBD pergolongan umur setelah itu pilih tahun.

\section{Tampilan Laporan Jumlah Kasus DBD}

Tampilan laporan jumlah kasus DBD dalam sistem ditunjukkan pada Gambar 14.

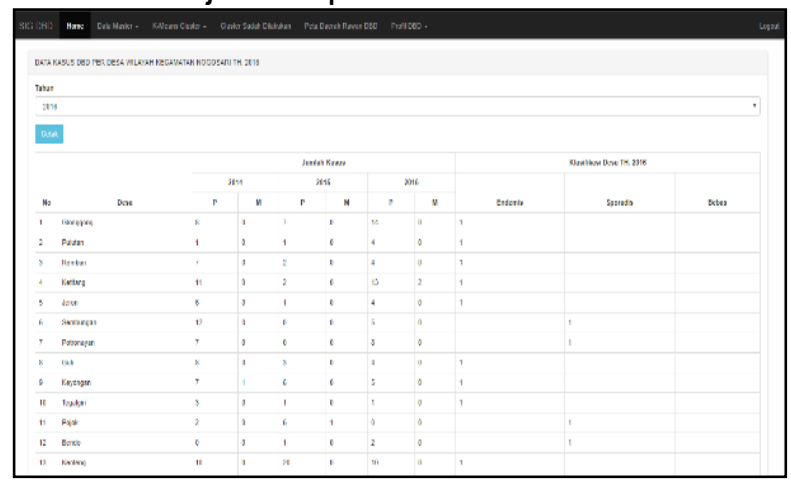

Gambar 14. Laporan Jumlah Kasus DBD

Pada laporan jumlah kasus DBD pergolongan umur pengguna dapat mencetak laporan dengan tombol cetak yang tersedia. Halaman laporan jumlah kasus DBD pergolongan umur dapat diakses dengan klik menu profil DBD kemudian pilih menu laporan jumlah kasus DBD setelah itu pilih tahun.

\section{Tampilan Grafik Tingkat Kerawanan Kasus DBD}

Tampilan grafik tingkat kerawanan kasus DBD dalam sistem ditunjukkan pada Gambar 15.

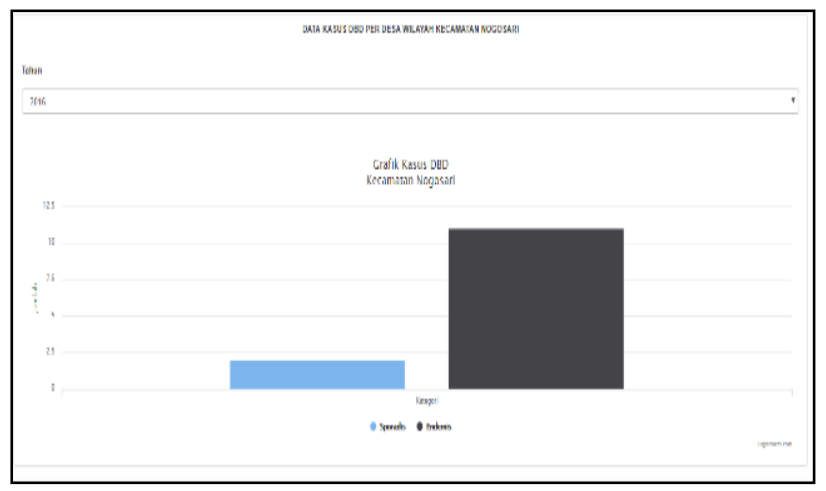

Gambar 15. Tampilan Grafik Tingkat Kerawanan Kasus DBD

Pada grafik tingkat kerawanan kasus DBD pengguna dapat statistik kasus DBD pertahun yang dipilih. Halaman grafik tingkat kerawanan kasus DBD dapat diakses dengan klik menu profil DBD kemudian pilih grafik tingkat kerawanan kasus DBD setelah itu pilih tahun.

\subsection{Pengujian Sistem}

1. Pengujian Fungsional (Black Box)

Berdasarkan hasil pengujian dengan menggunakan pengujian fungsionalitas (black box) yang telah dilakukan pada fungsi login, fungsi pengolahan kasus DBD, Fungsi pengolahan data pemetaan kasus DBD, pengkategorian zona DBD, Proses Cluster maka dapat ditarik kesimpulan bahwa sistem ini telah berjalan dengan optimal, hal ini dapat ditunjukkan melalui menu-menu yang telah berjalan sesuai fungsionalnya.

2. Pengujian Koefisien Silhouette

Hasil pengujian koefisien silhouette disajikan Tabel 5.

Tabel 5. Nilai Koefisien Silhouette

\begin{tabular}{|c|c|c|}
\hline Kelompok & Desa & $\begin{array}{l}\text { Nilai Koefisien } \\
\text { Silhouette }\end{array}$ \\
\hline \multirow{3}{*}{ Level 1} & Pulutan & 0.846840286 \\
\hline & Pojok & 0.815390341 \\
\hline & Bendo & 0.849890573 \\
\hline \multicolumn{2}{|c|}{$\begin{array}{l}\text { Rata-rata Nilai Koefisien Silhoette } \\
\text { Level } 1\end{array}$} & 0.837373733 \\
\hline \multirow{3}{*}{ Level 2} & Glonggong & 0.866609974 \\
\hline & Jeron & 0.851099032 \\
\hline & Potronayan & 0.857142857 \\
\hline \multicolumn{2}{|c|}{$\begin{array}{l}\text { Rata-rata Nilai Koefisien Silhoette } \\
\text { Level } 2\end{array}$} & 0.858283954 \\
\hline \multirow{3}{*}{ Level 3} & Guli & 0.77671823 \\
\hline & Keyongan & 0.724032273 \\
\hline & Kenteng & 0.819284703 \\
\hline \multicolumn{2}{|c|}{$\begin{array}{l}\text { Rata-rata Nilai Koefisien Silhoette } \\
\text { Level } 3\end{array}$} & 0.773345068 \\
\hline
\end{tabular}

Dari hasil pengujian validitas cluster yang dilakukan peneliti diatas pengelompokan daerah rawan DBD dengan metode koefisien silhouette, nilai rata-rata koefisien silhouette untuk level 1 adalah 0.837, level 2 adalah 0.858 , dan level 3 adalah 0.773 itu artinya objek telah berada dikelompok tepat atau bisa dikatakan hasil pengelompokkan Daerah rawan $\mathrm{DBD}$ ini sangat baik karena memiliki nilai rata-rata $S(i)>0,71$

3. Pengujian validitas sistem

Pengujian dilakukan dengan membandingkan hasil pengelompokan di UPTD puskesmas Nogosari dengan hasil pengelompokan dengan metode K-Means Clustering.Tabel perbandingan tersebut disajikan pada Tabel 6. 
Tabel 6. Perbandingan Pengelompokan UPTD Puskemas Nogosari dan $K$-Means Clustering

\begin{tabular}{|l|l|l|l|}
\hline Desa & $\begin{array}{l}\text { Hasil UPTD } \\
\text { Puskesmas } \\
\text { Nogosari } \\
\text { TH.2014 }\end{array}$ & $\begin{array}{l}\text { Hasil K-Means } \\
\text { Clustering } \\
\text { TH.2014 }\end{array}$ & Ket \\
\hline Glonggong & Endemis & Sporadis, Level 2 & Salah \\
\hline Pulutan & Sporadis & Sporadis, Level 1 & Benar \\
\hline Rembun & Endemis & Endemis, Level 1 & Benar \\
\hline Ketitang & Endemis & Endemis, Level 2 & Benar \\
\hline Jeron & Sporadis & Sporadis, Level 2 & Benar \\
\hline Sembungan & Endemis & Endemis, Level 3 & Benar \\
\hline Potronayan & Sporadis & Sporadis, Level 2 & Benar \\
\hline Guli & Sporadis & Sporadis, Level 3 & Benar \\
\hline Keyongan & Sporadis & Sporadis, Level 4 & Benar \\
\hline Tegalgiri & Endemis & Endemis, Level 1 & Benar \\
\hline Pojok & Sporadis & Sporadis, Level 1 & Benar \\
\hline Bendo & Sporadis & Sporadis, Level 1 & Benar \\
\hline Kenteng & Sporadis & Sporadis, Level 3 & Benar \\
\hline
\end{tabular}

Untuk menghitung akurasi dengan persamaan berikut :

$$
\begin{aligned}
\text { Akurasi Sistem } & =\frac{\text { Jumlah hasil benar }}{\text { jumlah semua data }} \times 100 \% \\
& =\frac{12}{13} \times 100 \% \\
& =92.31 \%
\end{aligned}
$$

Hasil uji validasi menunjukkan bahwa kinerja sistem sudah baik. Dapat dilihat dari prosentasi akurasi sistem terhadap data riil di lapangan mencapai $92.31 \%$. Dengan hasil dari sistem terdapat tambahan level dari setiap kategori.

\section{PENUTUP}

\subsection{Kesimpulan}

Dalam penelitian yang dilakukan menghasilkan beberapa kesimpulan, yaitu:

1. Sistem informasi geografis pemetaan daerah rawan DBD telah dapat dibangun dan memberikan informasi daerah rawan DBD kepada pengguna. Pada kasus pemetaan daerah rawan demam berdarah ini pengkategorian endemis, sporadis dan bebas menggunakan dasar penentuan dari UPTD Puskemas Kecamatan Nogosari. Selanjutnya di proses untuk pengelompokan Tingkat Kerawanan dari masing-masing kategori yang terbentuk.

2. Sistem Informasi Geografis Pemetaan Daerah Rawan Demam Berdarah Menggunakan Metode K-Means Di Kecamatan Nogosari Kabupaten Boyolali ini terdapat 2 level pengguna yaitu admin yang mendapatkan hak akses sebagai administrator untuk mengelola data master, proses pemetaan dengan clustering, melihat peta dan melihat profil DBD.
3. Dari hasil pengujian validitas cluster level zona sporadis DBD yang dilakukan peneliti dengan metode koefisien silhouette, nilai rata-rata koefisien silhouette untuk level 1 adalah 0.837, level 2 adalah 0.858, dan level 3 adalah 0.773 itu artinya objek telah berada dikelompok tepat.

4. Dari hasil pengujian akurasi sistem dengan data riil di lapangan menunjukkan bahwa kinerja sistem sudah baik dengan prosentasi akurasi sistem terhadap data riil di lapangan mencapai $92.31 \%$. Dengan hasil dari sistem terdapat tambahan level dari setiap kategori.

\subsection{Saran}

Berdasarkan hasil penelitian, maka dapat dikembangkan menjadi penelitian selanjutnya, yaitu:

1. Menggabungkan informasi pemetaan daerah rawan DBD dengan proses pencegahan dan penanggulangan yang harus dilakukan di lapangan

2. Menggunakan variasi metode yang lain untuk pemetaan daerah rawan DBD

\section{DAFTAR PUSTAKA}

[1] W. Falah, MengGambar Peta dengan ARCGIS 10.1. Andi Offset: Yogyakarta, 2015.

[2] E. Rivani, Aplikasi K-Means cluster untuk pengelompokkan provinsi berdasarkan produksi padi, jagung, kedelai, dan kacang hijau tahun 2009, J u r n al Mat Stat, Vol. 10 No. 2 Juli 2010: 122134, 2010.

[3] N. Suryana, Penggunaan Metode Statistik K-Means Clustering pada Analisis Peruntukan Lahan Usaha Tambang Berbasis Sistem Informasi Geografi, Statistika, Vol. 11 No. 1, 7 - 20 Mei 2011: 8-20, 2011.

[4] F. Kusuma, analisis tingkat kerentanan terhadap bahaya demam berdarah dengue (dbd) dengan menggunakan penginderaan jauh \& sistem informasi geografi di kecamatan banjarsari, kota Surakarta, Januari 2015:1-15, 2015.

[5] R. Andri, Pemanfaatan Citra Penginderaan Jauh dan Sistem Informasi Geografis untuk Pemetaan Daerah Rawan Demam Berdarah Dengue (Studi Kasus di Kecamatan Pangandaran Kabupaten Ciamis Provinsi Jawa Barat). Aspirator Vol. 3 No. 2 : 72-81. 2011. 